\title{
Studi Implementasi Good Governance Pemerintahan Daerah Kabupaten
}

\section{Bone Bolango}

\author{
Trisusanti Lamangida \\ Program Studi Administrasi Negara Universitas Muhammadiyah Gorontalo \\ Gorontalo,Indonesia \\ Email:tri.susanti@um-gorontalo.ac.id
}

\begin{abstract}
Some disadvantages show that the implementation of participation, transparency (transparency), responsiveness, and accountability principles in Bone Bolango County Government Office have not fulfilled the public expectation. Whereas the implementation or application of the principles of good governance is an important aspect in supporting the achievement of the objectives of the Regional Government. The purpose of this research is to know the application of Good Governance principles in Bone Bolango Regency Government. The research method used is qualitative approach with descriptive research type. The results of this study indicate that the implementation of the principle of Good Goveranance on Regional Government of Bone Bolango Regency has been running well but not yet maximal. There are still weaknesses in the implementation of good governance namely the transparency principle of weaknesses of government management transparency information has not been well developed.
\end{abstract}

Keywords: Implementation; Good governance; Government

\begin{abstract}
Abstrak
Beberapa kelemahan menunjukkan bahwa penerapan prinsip partisipasi (participation), transparansi (transparancy), daya tanggap (responsiveness), dan akuntabilitas (accountability) di Kantor Pemerintahan Kabupaten Bone Bolango belum memenuhi harapan masyarakat. Padahal implementasi atau penerapan prinsip-prinsip good governance merupakan aspek penting dalam mendukung pencapaian tujuan Pemerintah Daerah. Tujuan Penelitian ini ialah untuk mengetahui penerapan prinsip-prinsip Good Governance di Pemerintah Kabupaten Bone Bolango. Metode penelitian yang digunakan ialah pendekatan kualitatif dengan jenis peelitian deskriptif. Hasil dari penelitian ini menunjukkan bahwa pelaksanaan prinsip Good Goveranance pada Pemerintahan Daerah Kabupaten Bone Bolango sudah berjalan dengan baik tetapi belum maksimal. Masih terdapat kelemahan dalam implementasi good governance yakni prinsip transparansi kelemahan informasi manajemen transparansi pemerintahan belum berkembang dengan baik.
\end{abstract}

Kata Kunci : Implementasi; Good Governance; Pemerintah 


\section{PENDAHULUAN}

Good Governance atau tata pemerintahan yang baik, merupakan bagian dari paradigma baru yang berkembang dan memberikan nuansa yang cukup mewarnai pasca krisis multidimensi, seiring dengan tuntutan era reformasi. Dalam konteks Indonesia yang bergeliat dengan tuntutan reformasi, good governance tampil sebagai model transplantatif baru yang diyakini mampu mengobati birokrasi politik yang dinilai sarat korupsi, suap, dan penyalahgunaan kekuasan, termasuk berbagai pelanggaran hak-hak asasi manusia (Prianto, 2011:2)

Hardjasoemantri

mengemukakan bahwa Lima Tahun setelah dimulainya reformasi, keinginan untuk memperoleh good governace dan clean government masih jauh dari harapan. Berbagai kendala dalam bentuk gejolak politik, ekonomi, sosial budaya, hukum, pemerintahan yang simpang siur serta timbulnya ketidakpastian yang bermuara pada keresahan dan letupan-letupan yang justru membahayakan sendi-sendi kehidupan masyarakat.

Berlakunya otonomi daerah berdasarkan Undang-Undang Nomor 22 Tahun 1999 dan Undang-Undang Nomor 32 tahun 2004 tentang pemerintahan daerah, membuat perubahan yang sangat mendasar dalam sistem penyelenggaraan pemerintahan daerah dalam hal ini menegaskan bahwa pemerintah daerah bertanggung jawab sepenuhnya dalam penyelenggaraan pembangunan untuk meningkatkan taraf hidup masyarakat.

Sangat tingginya antusiasme serta respon positif masyarakat beberapa tahun ini terhadap sistem good governance menumbuhkan harapan terselenggaranya pemerintahan yang adil, terbuka dan bertanggung jawab. Hal tersebut sebagai akibat dari antara lain praktek

penyelenggaraan pemerintahan oleh aparatur di kantor Pemerintahan Daerah belum optimal. Kinerja organisasi kurang bahkan belum menggembirakan. Di samping itu, belum efektifnya perangkat hukum dan peraturan-peraturan Pemerintahan Daerah menjadi perhatian utama para akademisi dan praktisi untuk membenahi serta menata kembali sistem pemerintahan.

Dalam menjalankan tugas-tugas pemerintahan, Pemerintahan Kabupaten Bone Bolango sebagai bagian dari sistem pemerintahan di Indonesia memiliki tekad dan spirit untuk melaksanakan sistem pemerintahan berbasis prinsip good governance. Tekad dan spirit ini didukung oleh adanya beberapa wadah dan kelembagaan Pemerintahan Kabupaten yang mendukung pelaksanaan prinsipprinsip good governance, adanya komitmen elite atau pembuat kebijakan untuk mendukung dilaksanakan prinsipprinsip good governance dan adanya tuntutan warga masyarakat Kabupaten Bone Bolango untuk terselenggaranya pemerintahan berbasis good governance.

Namun kenyataan di lapangan menunjukkan bahwa implementasi prinsipprinsip good governance di Kantor Pemerintahan Kabupaten Bone Bolango masih memiliki kelemahan. Diantaranya sebagian masyarakat belum dilibatkan secara aktif dalam pembuatan keputusan yang dilakukan oleh Pemerintah Daerah. terdapat masyarakat yang masih mengalami kesulitan untuk mengetahui informasi tentang kebijakan, program, dan kegiatan aparatur Pemerintah Daerah. Serta masyarakat masih menganggap bahwa Pemerintah Daerah masih lambat dalam merespon keluhan masyarakat terutama terkait dengan lambannya pengurusan surat izin. Bahkan masyarakat menilai bahwa 
pemerintah daerah Kabupaten Bone Bolango kurang akuntabel dalam melaporkan harta kekayaan yang dimiliki terutama pada saat awal memegang jabatan.

Beberapa kelemahan tersebut di atas menunjukkan bahwa penerapan prinsip partisipasi (participation), transparansi (transparancy), daya tanggap (responsiveness), dan akuntabilitas (accountability) di Kantor Pemerintahan Kabupaten Bone Bolango belum memenuhi harapan masyarakat. Padahal implementasi atau penerapan prinsipprinsip good governance merupakan aspek penting dalam mendukung pencapaian tujuan Pemerintah Daerah. Adanya kelemahan tersebut yang mendorong untuk dilakukan penelitian ini.

\section{METODE PENELITIAN}

Pendekatan penelitian yang digunakan adalah pendekatan kualitatif, dengan jenis penelitian deskriptif yaitu memberikan gambaran tentang implementasi prinsip-prinsip good governance pada Pemerintahan Kabupaten Bone Bolango.

Sumber data dalam penelitian terdiri dari data primer dan data sekunder. Informan dalam penelitian ini ditentukan berdasarkan pertimbangan bahwa informan memahami tentang proses implementasi good governance pada Pemerintahan Kabupaten Bone Bolango, yang dikonfirmasikan kepada informan berjumlah 20 orang. Teknik analisis data dengan langkah-langkah analisis data sebagai berikut: Reduksi data, Display data dan Penarikan kesimpulan dan verifikasi Untuk memberikan gambaran data tentang hasil penelitian, maka dilakukan prosedur sebagai berikut: tahap penyajian data, tahap komparasi, serta tahap penyajian hasil penelitian
Teknik pengumpulan data yang digunakan adalah teknik observasi, wawancara dan telaah dokumen. Pemeriksaan keabsahan data yang digunakan dalam penelitian ini berdasarkan teknik yang dikemukakan oleh Maleong (2001:32), yaitu : perpanjangan keikutsertaan, ketekunan pengamatan, triangulasi data.

\section{HASIL DAN PEMBAHASAN}

Berdasarkan Peraturan Daerah Kabupaten Bone Bolango Nomor 8 tahun 2010, penyelenggaraan Pemerintahan Kabupaten Bone Bolango dipimpin Bupati Kabupaten Bone Bolango. Secara organisatoris, Bupati membawahi Sekretariat Daerah, Sekretariat Dewan Perwakilan Rakyat Daerah, Dinas Daerah, Lembaga Teknis, Badan Perencanaan Pembangunan Daerah, Inspektorat, Satuan Polisi Pamong Praja, Rumah Sakit Umum Daerah. Dalam menyelenggarakan pemerintahan, Bupati dibantu oleh Staf Ahli Bidang Kebijakan Publik dan Hukum, dan Staf Ahli Bidang Ekonomi, Keuangan, dan Pembangunan.

Visi Kabupaten Bone Bolango yaitu: "Terwujudnya masyarakat Gorontalo yang mandiri, berbudaya entrepeneur dan bersandar pada moralitas agama dalam kerangka Negara Kesatuan Republik Indonesia". Misi Kabupaten Bone Bolango yaitu: "Terwujudnya sistim demokrasi dan supremasi hukum melalui praktek penyelenggaraan pemerintahan yang bersih, transparan dan professional, melakukan restrukturisasi, refungsionalisasi dan revitalisasi lembagalembaga pemerintahan, kemasyarakatan, adat sebagai wahana ke arah terwujudnya Entrepreneurial Government dan masyarakat yang mandiri Meningkatkan peran masyarakat sebagai mitra dan pelaku utama pembangunan daerah. 
Ada 3 (tiga) sektor fokus yang diharapkan dapat menjadi sektor basis (base sectors) pembangunan daerah dalam kurun waktu 5 (lima) tahun kedepan, yaitu: sektor pendidikan, sektor kesehatan dan sektor infrastruktur wilayah. Pengembangan ketiga sektor basis ini diarahkan untuk menjadi penopang utama dan pembuka peluang bagi berkembangnya sektor-sektor pembangunan daerah lainnya. Sedangkan untuk memperkuat daya tumbuh bagi pembangunan ekonomi daerah dalam 5 (lima) tahun kedepan, program strategis yang akan menjadi program unggulan (leading program), yakni: 1) Pengembangan Sumber Daya Manusia. 2) Pengembangan Pariwisata Daerah. 3) Pengembangan Usaha Pertanian dan Perikanan. 4) Pengembangan Usaha Industri Berbasis Sumber Daya Lokal (Resources Base).

Hasil wawancara tentang implementasi prinsip-prinsip good governance di Pada Pemerintahan Daerah Kabupaten Bone Bolango dirangkum dalam uraian sebagai berikut: secara umum penerapan prinsip good governance pada pemerintahan daerah Kabupaten Bone Bolango sudah berjalan namun belum efektif. Hal ini dapat dilihat dari tingkat penerapan prinsip partisipasi, prinsip transparansi, prinsip daya tanggap, prinsip akuntabilitas di Pada Pemerintahan Daerah Kabupaten Bone Bolango, belum sesuai harapan masyarakat dan amanah Undang Undang otonomi daerah, yakni terwujudnya pemerintahan yang baik dan bersih.

Good governance di Kantor Pemerintahan Daerah Kabupaten Bone Bolango merupakan pelayanan publik partisipatif, transparan, responsif serta pemerintahan yang bertanggungjawab pada publiknya. Pada hakikatnya, penyelenggaraan Pemerintahan Daerah
Kabupaten Bone Bolango ditujukan kepada terciptanya fungsi pelayanan publik (publik service). Pemerintahan yang baik cenderung menciptakan terselenggaranya fungsi pelayanan publik dengan baik pula. Sebaliknya, pemerintahan yang buruk mengakibatkan fungsi pelayanan publik tidak akan dapat terselenggara dengan baik.

Prinsip tata kelola Pemerintahan Daerah Kabupaten Bone Bolango yang baik, tidak hanya terbatas pada penggunaan peraturan perundangundangan yang berlaku, melainkan dikembangkan dengan menerapkan prinsip penyelenggaraan pemerintahan yang baik yang tidak hanya melibatkan Pemerintah Daerah Kabupaten Bone Bolango semata, tetapi harus melibatkan sistem birokrasi maupun ekstern birokrasi.

Good governance di Kantor Pemerintahan Daerah Kabupaten Bone Bolango bukan semata-mata mencakup relasi dalam pemerintahan, melainkan mencakup relasi sinergis dan sejajar antara pasar, pemerintah dan masyarakat Bone Bolango. Gagasan kesejajaran ini mengandung arti akan pentingnya redifinisi peran dan hubungan ketiga institusi ini dalam mengelola sumberdaya ekonomi, politik, dan kebudayaan yang tersedia dalam masyarakat Bone Bolango.

Prinsip artisipasi (participation) di Kantor Pemerintahan Daerah Kabupaten Bone Bolango pada hakikatnya adalah keterlibatan masyarakat Bone Bolango dalam pembuatan keputusan baik secara langsung maupun tidak langsung melalui lembaga perwakilan (legislatif) yang dapat menyalurkan aspirasi mereka. Partisipasi tersebut dibangun atas dasar kebebasan berasosiasi dan berbicara serta berpartisipasi secara konstruktif melalui mekanisme komunikasi yang dibangun 
oleh Pemerintah Daerah Kabupaten Bone Bolango.

\section{Pemerintah Daerah Kabupaten}

Bone Bolango harus mampu mendorong setiap masyarakat untuk menggunakan hak dalam menyampaikan pendapat dalam proses pengambilan keputusan yang menyangkut kepentingan publik. Dalam partisipasi masyarakat, semua warga masyarakat Bone Bolango mempunyai suara dalam pengambilan keputusan, baik secara langsung maupun melalui lembagalembaga perwakilan yang sah yang mewakili kepentingan mereka.

Partisipasi menyeluruh masyarakat

Bone Bolango dibangun berdasarkan kebebasan berkumpul dan mengungkapkan pendapat, serta kepastian untuk berpartisipasi secara konstruktif. Masyarakat yang berkepentingan ikut serta dalam proses perumusan dan/atau pengambilan keputusan atas kebijakan publik yang diperuntukkan bagi masyarakat.

Prinsip transparansi (transparancy) di Kantor Pemerintahan Daerah Kabupaten Bone Bolango pada hakikatnya dibangun atas dasar kebebasan memperoleh informasi. Informasi yang berkaitan dengan kepentingan masyarakat bone Bolango secara langsung dapat diperoleh oleh mereka yang membutuhkan.

Pemerintah Daerah Kabupaten Bone Bolango harus mampu menciptakan kepercayaan timbal balik antara pemerintah dan masyarakat melalui penyediaan informasi dan menjamin kemudahan untuk mendapatkan informasi. Wujud nyata prinsip tersebut antara lain dapat dilihat apabila masyarakat Bone Bolango mempunyai kemudahan untuk mengetahui serta memperoleh data dan informasi tentang kebijakan, program, dan kegiatan aparatur pemerintah, baik yang dilaksanakan di tingkat pusat maupun daerah. daya

tanggap

(responsiveness) di Kantor Pemerintahan Daerah Kabupaten Bone Bolango pada hakikatnya mengandung arti bahwa Kantor Pemerintahan Daerah Kabupaten Bone Bolango pada hakikatnya harus cepat dan tanggap dalam melayani stakeholders dan masyarakat. Dalam hal ini bertujuan untuk meningkatkan kepekaan Pemerintah Daerah Kabupaten Bone Bolango terhadap aspirasi masyarakat tanpa pengecualian. Pemerintah Daerah Kabupaten Bone Bolango harus cepat tanggap terhadap perubahan situasi/kondisi mengakomodasi aspirasi masyarakat, serta mengambil prakarsa untuk mengatasi berbagai masalah yang dihadapi masyarakat Bone Bolango.

Prinsip akuntabilitas (accountabili

ty) di Kantor Pemerintahan Daerah Kabupaten Bone Bolango pada hakikatnya merupakan pertanggungjawaban kepada masyarakat Bone Bolango atas setiap aktivitas yang dilakukan, bertujuan untuk meningkatkan akuntabilitas Pemerintah Daerah Kabupaten Bone Bolango dalam segala bidang yang menyangkut kepentingan masyarakat luas. Para pengambil keputusan di Kantor Pemerintahan Daerah Kabupaten Bone Bolango bertanggungjawab, baik kepada masyarakat maupun kepada lembagalembaga yang berkepentingan.

Akuntabilitas, mencakup eksistensi dari suatu mekanisme (baik secara konstitusional maupun keabsahan dalam bentuknya) di Kantor Pemerintahan Daerah Kabupaten Bone Bolango yang memberikan keyakinan kepada politisi dan pejabat pemerintahan di Kantor Pemerintahan Daerah Kabupaten Bone Bolango terhadap aksi perbuatannya dalam penggunaan sumber-sumber publik dan performa perilakunya.

Akuntabilitas di Kantor Pemerintahan Daerah Kabupaten Bone 
Bolango membutuhkan keterbukaan dan kejelasan serta keterhubungannya dengan kebebasan media. Kantor Pemerintahan Daerah Kabupaten Bone Bolango dan para aparaturnya harus dapat mempertanggungjawabkan pelaksanaan kewenangan yang diberikan sesuai dengan tugas dan fungsinya. Demikian halnya dengan kebijakan, program, dan kegiatan yang dilakukannya.

Prinsip-prinsip good governance di Kantor Pemerintahan Daerah Kabupaten Bone Bolango sebagaimana tersebut diatas hanya bermakna bila keberadaannya ditopang oleh tiga domain yang melibatkan kepentingan masyarakat Bone Bolango. Upaya untuk mewujudkan tata kepemerintahan yang baik hanya dapat dilakukan apabila terjadi keseimbangan peran ketiga pilar yaitu Pemerintah Daerah Kabupaten Bone Bolango, dunia usaha swasta, dan masyarakat Bone Bolango. Ketiga unsur tersebut dalam memainkan perannya masing-masing harus sesuai dengan nilai-nilai dan prinsip-prinsip yang terkandung dalam tata kepemerintahan yang baik.

Pemerintah Daerah Kabupaten Bone Bolango dapat menciptakan kondisi politik, ekonomi dan sosial yang stabil, membuat peraturan yang efektif dan berkeadilan, menyediakan public service yang efektif dan accountable, menegakkan Hak Asasi Manusia, melindungi lingkungan hidup, serta mengurus standar kesehatan dan standar keselamatan publik. Sedangkan sektor swasta dapat menjalankan industry, menciptakan lapangan kerja, menyediakan insentif bagi karyawan, meningkatkan standar hidup masyarakat, memelihara lingkungan hidup, menaati peraturan, transfer ilmu pengetahuan dan tehnologi kepada masyarakat, dan menyediakan kredit bagi pengembangan usaha kecil menengah.
Sementara itu, masyarakat madani Bone Bolango dapat menjaga agar hak-hak masyarakat terlindungi, mempengaruhi kebijakan publik, sebagai sarana cheks and balances pemerintah, mengawasi penyalahgunaan kewenangan sosial pemerintah, mengembangkan sumber daya manusia dan sarana berkomunikasi antar anggota masyarakat.

Pada hakikatnya mewujudkan good governance sulit dilaksanakan dalam prakteknya di Kantor Pemerintahan Daerah Kabupaten Bone Bolango. Namun, dengan adanya Undang-Undang Nomor 22 Tahun 1999 dan Undang-Undang Nomor 32 tahun 2004 tentang Pemerintahan Daerah, terdapat harapan dan cita-cita untuk bisa mewujudkan good governance di Kantor Pemerintahan Daerah Kabupaten Bone Bolango. Semangat otonomi daerah yang luas, nyata dan bertanggung jawab di bawah kedua Undang-Undang tersebut secara ideal dapat mendorong terwujudnya good governance pada penyelenggaraan pemerintahan daerah di Kabupaten Bone Bolango. Semangat otonomi daerah tersebut akan memacu pelaksanaan pembangunan daerah, peningkatan pelayanan kepada masyarakat Bone Bolango, dan mendorong tumbuh dan berkembangnya demokrasi.

Kondisi tersebut dapat diwujudkan karena Pemerintah Daerah Kabupaten Bone Bolango memiliki kewenangan yang luas untuk mengatur dan mengurus kepentingan masyarakat Bone Bolango menurut prakarsa sendiri berdasarkan aspirasi masyarakat sesuai dengan peraturan perundang-undangan. Berdasarkan Undang-Undang Nomor 32 tahun 2004, Pemerintah Daerah Kabupaten Bone Bolango memiliki kewenangan yang luas dan utuh.

Dalam pengertian di atas, maka Pemerintah Daerah Kabupaten Bone 
Bolango tidak lagi menunggu lagi penyerahan kewenangan dari pusat tapi bisa mengembangakan kewenangan yang dimiliki berdasarkan Undang-Undang tersebut sesuai dengan kondisi riil di Kabupaten Bone Bolango. Sedangkan utuh artinya bahwa dalam melaksanakan kewenangan .yang telah diserahkan tersebut mulai dari perencanaan, pelaksanaan, dan evaluasi merupakan tanggung jawab Pemerintah Daerah Kabupaten Bone Bolango sepenuhnya. Pemerintahan pusat tidak lagi mencampurinya. Pemerintah pusat hanya memberikan pedoman, arahan, bimbingan dan penentuan standarnya.

Implementasi prinsip partisipasi (participation), transparansi (transparancy), daya tanggap (responsiveness), dan akuntabilitas (accountability) di Kantor Pemerintahan Kabupaten Bone Bolango sudah menjadi kebutuhan yang tidak dapat diabaikan lagi. Format dan konsep good governance yang diimplementasikan dalam penyelenggaraan pemerintahan di Kantor Pemerintahan Kabupaten Bone Bolango merupakan penjabaran lebih lanjut dari azas-azas umum penyelenggaraan negara sebagaimana diatur oleh Undang-Undang Nomor 28 tahun 1999 tentang Penyelenggaraan Negara yang Bersih dan Bebas Korupsi, Kolusi dan Nepotisme.

Isu good governance di Kantor Pemerintahan Kabupaten Bone Bolango didorong oleh adanya dinamika yang menuntut perubahan-perubahan di sisi pemerintah maupun di sisi masyarakat Bone Bolango. Pemerintah Kabupaten Bone Bolango diharapkan menjadi lebih demokratis, efisien dalam penggunaan sumber daya publik, efektif menjalankan fungsi pelayanan publik, lebih tánggap serta mampu menyusun kebijakan, program dan hukum yang dapat menjamin hak asasi dan keadilan sosial.

Agenda penciptaan good
governance Kantor Pemerintahan Kabupaten Bone Bolango memiliki 5 (lima) sasaran yaitu: 1) Berkurangnya secara nyata praktek korupsi, kolusi dan nepotisme di birokrasi Kantor Pemerintahan Kabupaten Bone Bolango, yang dimulai dari jajaran pejabat yang paling atas sampai pada staf bawah. 2) Terciptanya sistem kelembagaan dan ketatalaksanaan pemerintah yang efisien, efektif dan profesional, transparan dan akuntabel. 3) Terhapusnya peraturan dan praktek yang bersifat diskriminatif terhadap masyarakat Bone Bolango. 4) Meningkatnya partisipasi masyarakat dalam pengambilan kebijakan publik. 5) Terjaminnya konsistensi seluruh peraturan pusat dan daerah.

\section{PENUTUP}

\section{Kesimpulan}

Berdasarkan hasil penelitian dan pembahasan diperoleh kesimpulan sebagai berikut: Implementasi prinsip Good Goveranance pada Pemerintahan Daerah Kabupaten Bone Bolango sudah berjalan dengan baik tetapi belum maksimal. Masih terdapat kelemahan dalam implementasi good governance yakni prinsip transparansi kelemahan informasi manajemen transparansi pemerintahan belum berkembang dengan baik. Selanjutnya implementasi prinsip daya tanggap responsivitas aparat cenderung lambat dengan waktu tunggu penyelesaian sengketa yang dirasakan lama. Prinsip akuntabilitas masyarakat sangat berharap agar bentuk laporan pertanggunganjawaban perlu untuk dipublikasikan melalui media

\section{Saran}

Berdasarkan kesimpulan penelitian, maka beberapa saran yang dapat diberikan dalam penelitian ini yaitu: Dalam upaya mengoptimalkan implementasi prinsip 
partisipasi pada Pemerintahan Daerah Kabupaten Bone Bolango, perlu melakukan kegiatan debat publik secara rutin dan terprogram setiap minggu sampai ke tingkat desa, dan membentuk lembagalembaga advokasi di tingkat kecamatan. Dalam upaya mengoptimalkan implementasi prinsip transparansi Pada Pemerintahan Daerah Kabupaten Bone Bolango perlu mengembangkan sistem informasi manajemen transparansi pemerintahan melalui E-government. Serta Dalam upaya mengoptimalkan implementasi prinsip daya tanggap perlu membentuk Tim Penyelesaian Sengketa Masyarakat

\section{DAFTAR PUSTAKA}

Best, John W. 1982. Research in Education. Prentice-Hall.

Hardjasoemantri, Koesnadi. 2003. Good Governance Dalam Pembangunan Berkelanjutan Di Indonesia. Makalah Untuk Lokakarya Pembangunan Hukum Nasional ke VIII di Bali, tanggal 15 Juli 2003.

Prianto, A. L. (2011). Good Governance dan Formasi Kebijakan Publik Neo-Liberal. Otoritas: Jurnal Ilmu Pemerintahan, 1(1).

Moleong, Lexy J. 2001. Metodologi Penelitian Kualitatif. Bandung : Rosdakarya

Mustopadidjaja, AR. 2003. Manajemen Proses Kebijakan Publik, Formulasi, Implementasi dan Evaluasi Kinerja. Jakarta.: Penerbit LAN,

Nurcholis, Hanif. 2007. Teori dan Praktek Pemerintahan dan Otonomi Daerah. Jakarta : PT. Gramedia Widiasarana Indonesia.

Peraturan Daerah No. 8 Tahun 2010, Kabupaten Bone Bolango
Sedarmayanti. 2003. Kepemerintahan yang Baik dalam Rangka Otonomi Daerah. CV. Bandung: Mandar Maju

Sugiyono, 2010. Memahami Penelitian Kualitatif. Bandung.: Penerbit CV Alfabeta.

Tahir, Arifin. 2011. Kebijakan Publik dan Transparansi Penyelenggaraan Pemerintahan Daerah. Jakarta: PT Pustaka Indonesia Press.

Undang-Undang Republik Indonesia Nomor 22 Tahun 1999.

Pemerintahan Daerah. Jakarta.: CV. Eko Jaya

Undang-Undang Republik Indonesia Nomor 32 Tahun 2004. Pemerintahan Daerah. Jakarta.: CV. Eko Jaya 